\title{
Investigation of membrane potential changes in Nitellopsis obtusa cells induced by blue and red light stimulation
}

\author{
Vilma Kisnierien $\dot{e}^{\star}$, \\ Jonas Burneika, \\ Indrè Lapeikaitè, \\ Olga Sevriukova, \\ Algis Daktariūnas \\ Department of Neurobiology \\ and Biophysics, \\ Faculty of Natural Sciences, \\ Vilnius University, \\ M. K. Čiurlionio str. 21/27, \\ LT-03101 Vilnius, \\ Lithuania
}

Light controls multiple physiological processes in plants. Membrane potential is widely used to report the early events associated with changes in ion permeability, thus the effect of monochromatic light on bioelectrical parameters of Nitellopsis obtusa cells was examined. In this study blue, red and far-red light-induced membrane potential changes, light-induced photoelectrical reaction and membrane excitability were investigated using $\mathrm{K}$-anaesthesia method. All investigated lights cause the same bioelectrical events in Nitellopsis obtusa cells. It can be concluded that all photoreception systems exert their effects by first altering the permeability of the plasma membrane to ions and later ion channels perform signal-transducing functions in the complex array of mechanisms that determine plant physiology.

Key words: plant photoreceptors, membrane potential, plant electrical signalling, plant photoelectrical reaction

\section{INTRODUCTION}

Light is a key factor for metabolism as well as a source of information in plant kingdom. Different light absorbing systems are reported to exist in plants. Aside from the light harvesting complexes that participate in photosynthesis, complex, multiple photoreception systems participate in physiological processes, and the major of them are red/far-red light-sensing phytochromes and blue

\footnotetext{
* Corresponding author. E-mail: vilma.kisnieriene@gf.vu.lt
}

light-sensing phototropins and cryptochromes (Briggs and Olney, 2001). Photosynthetic pigments, mainly chlorophylls, can play a role as photoreceptors, too (Okazaki et al., 1994). Upon illumination, a complex interaction between these photoreceptors occurs (Živanović et al., 2005). During their "cross-talk" information on light quantity and quality is gained and eventually translated into signals controlling physiological functions (Franklin and Whitelam, 2004). However, the mechanisms by which these photoreceptors generate many diverse 
physiological responses remain unknown. It could be electrical signaling, because changes in plasma membrane potential (MP) are amongst the earliest cellular events in response to light (Szarek and Trebacz, 1999). It is suggested that light controls ion movements across the cell membrane (Shabala and Newman, 1999). To date, the link between light absorption by photoreception system and ion fluxes across the plasma membrane remains unclear. Among the factors which can participate in the transduction process changes in $\mathrm{Ca}^{2+}$ are often postulated (Ermolayeva et al., 1996). It is established that $\mathrm{Ca}^{2+}$ signaling and fluxes through ion channels are responsible for action potential generation (AP) and photoelectrical reaction in plants (Kurtykaet et al., 2011). In Characeae cells the ionic mechanism causing AP was characterized in detail. According to the generally accepted model, an AP is initiated by calcium influx into the cytosol followed by $\mathrm{Cl}^{-}$efflux (Lunevsky et al., 1983). Chloride ions leave the cell down their electrochemical potential gradient through $\mathrm{Ca}^{2+}$ activated anion channels. Repolarization occurs after opening of voltage-gated potassium channels allowing $\mathrm{K}^{+}$efflux (Thiel et al., 1997). It was suggested that supposedly the second stage of repolarization during $\mathrm{AP}$ is related to the operation of electrogenic H-pump in the plant excitable membrane (Sukhov et al., 2011). It has already been demonstrated that the membrane potential of Characean cells is very sensitive to light / dark and dark / light transition (so called photoelectrical reaction) and a typical reaction on this transition consists of two phases - a rapid transient depolarization of the MP followed by a slow membrane hyperpolarization (Shimmen et al., 1994). As the primary event, when an action potential (AP) is induced in Characeae cells is an increase in cytosolic $\mathrm{Ca}^{2+}$ level (Beilby, 2007), it is interesting to investigate Characeaen electrical excitability in monochromatic light. Light induced action potentials (APs) are known in excitable plants (Koselski et al., 2008). Moreover, shade induced APs were also reported in plants (Stahlberg, 2006), so it is interesting to investigate light exposure on Chlarophyceae alga electrical events that may be recorded from individual cells. It was shown that some red-light effects, for example spore germination, are antagonistic to blue light, red and blue-light effects can also be the same or synergistic (Kagawa and Wada, 1996). So it is interesting to observe effect of monochromatic light on bioelectrical parameters because membrane potential is widely used to report for early events associated with changes in ion permeability. Electrophysiological techniques could be employed to characterize bioelectrical properties in in vivo conditions after monochromatic light irradiation.

The technology based on light-emitting diodes (LEDs) expanded the possibilities to analyze the effects of different lighting spectra on plant physiological processes. The aim of this study was to examine blue, red and far-red light induced membrane potential changes and exitability in Nitellopsis obtusa cells.

\section{MATERIALS AND METHODS}

Cells of Nitellopsis obtusa were collected in November from Lake Siesartis (Lithuania) and were kept in a glass aquarium filled with ordinary room temperature water. Prior to the experiment, internodal cells (second or third internode below the tip of growing plants) were separated from neighboring cells.

The internodes were kept in the dark overnight in APW (control solution for electrophysiological testing) containing $0.1 \mathrm{mM} \mathrm{KCl}$, $1.0 \mathrm{mM} \mathrm{NaCl}, 0.1 \mathrm{mM} \mathrm{CaCl}_{2}$, and $5 \mathrm{mM} \mathrm{THS/}$ RIS buffer, $\mathrm{pH}$ 7.2. Registration of membrane parameters is carried out according to $\mathrm{K}^{\prime}$ anaesthesia method (Kisnieriene et al., 2008).

Plexiglas chamber with $\mathrm{Ag} / \mathrm{AgCl} 2$ electrodes for cells stimulation and biopotential registration was used. One end of the cell is placed in the larger a-pool. The small segment (about $1 \mathrm{~mm}$ ) of each cell is positioned in the common central c-pool, filled with $100 \mathrm{mM} \mathrm{KCl}$ solution. Electrical isolation between pools is achieved with $5 \%$ boric vaseline junctions as well as by an air gap between them (Fig. 1). The cell parts 


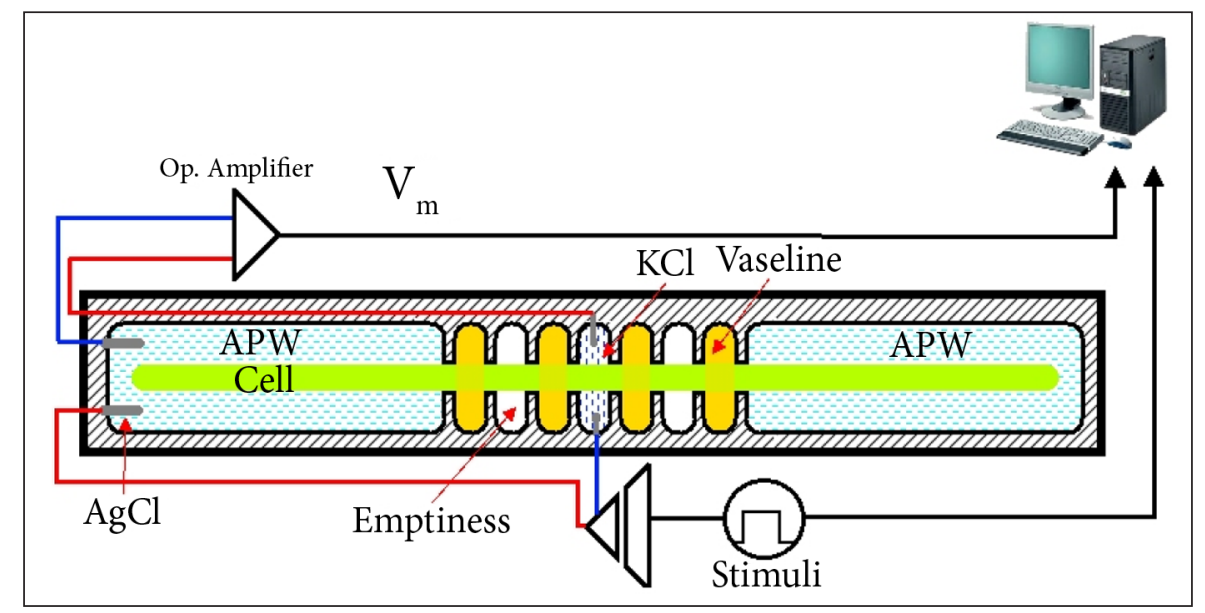

Fig. 1. Schematic diagram of the experimental set-up

in the pools are continuously bathed with APW solution. Bioelectrical signals are obtained from one general reference electrode placed in a reference pool, similar to an a-pool, and from appropriate measuring electrodes. The electrical contact between pools is enabled through the P-shaped glass tube bridge plugged with 3\% $(\mathrm{w} / \mathrm{v})$ agar solidified in a $3 \mathrm{M} \mathrm{KCl}$ solution.

Every 5 minutes three action potentials were elicited by injecting $0.1 \mathrm{~s}$ duration square pulse to threshold depolarizing current between two pools using $\mathrm{Ag} / \mathrm{AgCl}$ wires. Two 12 bits ana$\log$ outputs and 24 bits digital outputs of the "e-Biol" DAQ permit to easily implement any algorithm of stimulation. Signals were amplified with a WPI DAM50 preamplifier (input impedance - $10^{12} \Omega$, input leakage current - $50 \mathrm{pA}$, gain - 20x). Data were A/D converted (12 bits, ADS7806P) and stored in the computer memory for later analysis of membrane parameters. As data acquisition device "e-Biol" system was used.

LED arrays $(10 \times 100 \times 1 \mathrm{~mm})$ constructed from $5 \mathrm{~mm} \mathrm{GaAlAs} 18 \mathrm{~mW} / \mathrm{cm}^{2}$ power Roithner Lasertechnik GmbH, LED's (430 nm, 660 nm ir $730 \mathrm{~nm}$ ) were used as monochromatic light source. Light intensity was adjustable using potentiometer.

Photoelectric reaction was monitored 1 hour after light / dark and dark / light transition. Three AP were evoked every 5 minutes in the dark and after every illumination (Fig. 2).

Data are presented as mean and standard error. Statistical significance of differences was tested using paired $\mathrm{T}$ test and unpaired $\mathrm{T}$ test. All statements on statistical significance are

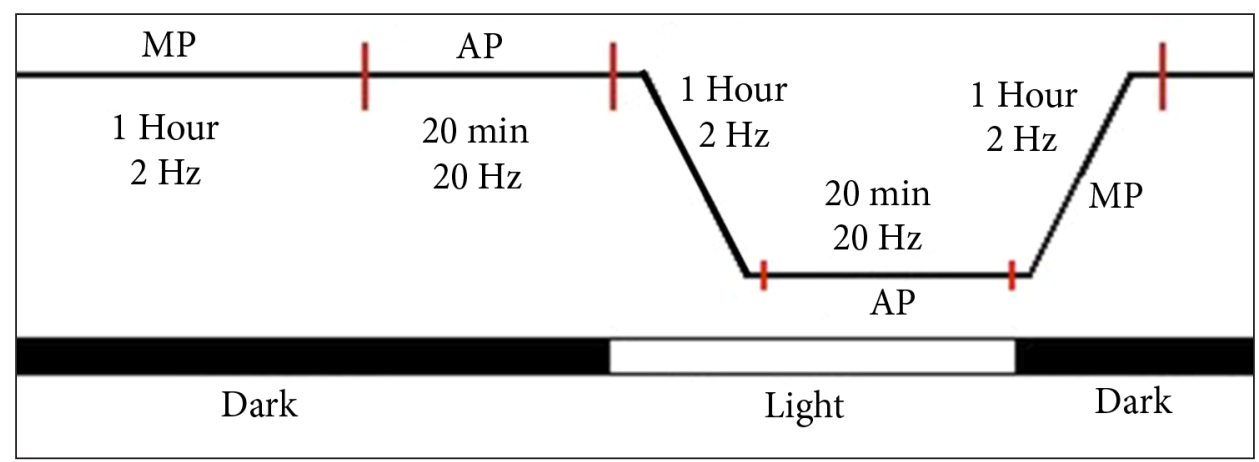

Fig. 2. The experimental protocol. Membrane potential (MP) recording without excitation continued $1 \mathrm{~h}$ at $2 \mathrm{~Hz}$ sampling frequency in the dark and after monochromatic illumination. Action potential (AP) recording continued $20 \mathrm{~min}$ at $20 \mathrm{~Hz}$ sampling frequency 
based on confidence level of 95\%. Calculations and statistical analysis were performed using Microcal ORIGIN 7.5, Statistica 6.0 (StatSoft).

\section{RESULTS AND DISCUSSION}

Light controls multiple physiological processes involving several light receptor systems. In this study we observed monochromatic lightinduced photoelectrical reaction and membrane excitability in Nitellopsis obtusa cells. The effect of monochromatic blue, red and far-red light on membrane potential changes was evaluated using $\mathrm{K}$ '-anaesthesia method. Two processes of different polarity and time constants were observed in all cells when light was switched on and off. Illumination evokes a long-lasting hyperpolarization preceded by a small transient depolarization (Fig. 3). Switching off all investigated lights evokes long-lasting depolarization preceded by small transient hyperpolarization.

The rapid transient depolarization of membrane was observed in all investigated cells (8 cells in every light), but in some cells (3) after dark / red light transition depolarization amplitude was small. Statistical analysis showed this effect to be not significant and every monochromatic light caused the same depolarization $(p>0.5)$. If the cell was irridated by far-red light and then, after 2 hours of darkness, red light was swiched on, we observed statistically significant increase in depolarization amplitude $(\mathrm{p}<0.01)$. It is known that $\mathrm{Ca}^{2+}$ plays a role as a "second messenger" that mediates the light perception and it was shown that $\mathrm{Ca}^{2+}$ carries a significant portion of the depolarizing current (Ermolayeva et al., 1996). Other investigators have shown that blue light but not red light induces a calcium transient in the moss Physcomitrella patens (Russell et al., 1998). In Vallisneria gigantea Graebner mesophyll cells, red light irradiation induces cytoplasmic streaming by decreasing the $\mathrm{Ca}^{2+}$ concentration in the cytoplasm, while far-red light irradiation inhibits it by increasing the concentration (Shabala et al., 1999). Our results indicate that all investigated lights induce increment of cytoplasmic $\mathrm{Ca}^{2+}$ concentration in Nitellopsis obtusa cells.

Slow membrane hyperpolarization followed every light swiching on. We could observe two patterns of MP changes (Fig. 3), but it depends not on the efect of monochromatic light, but

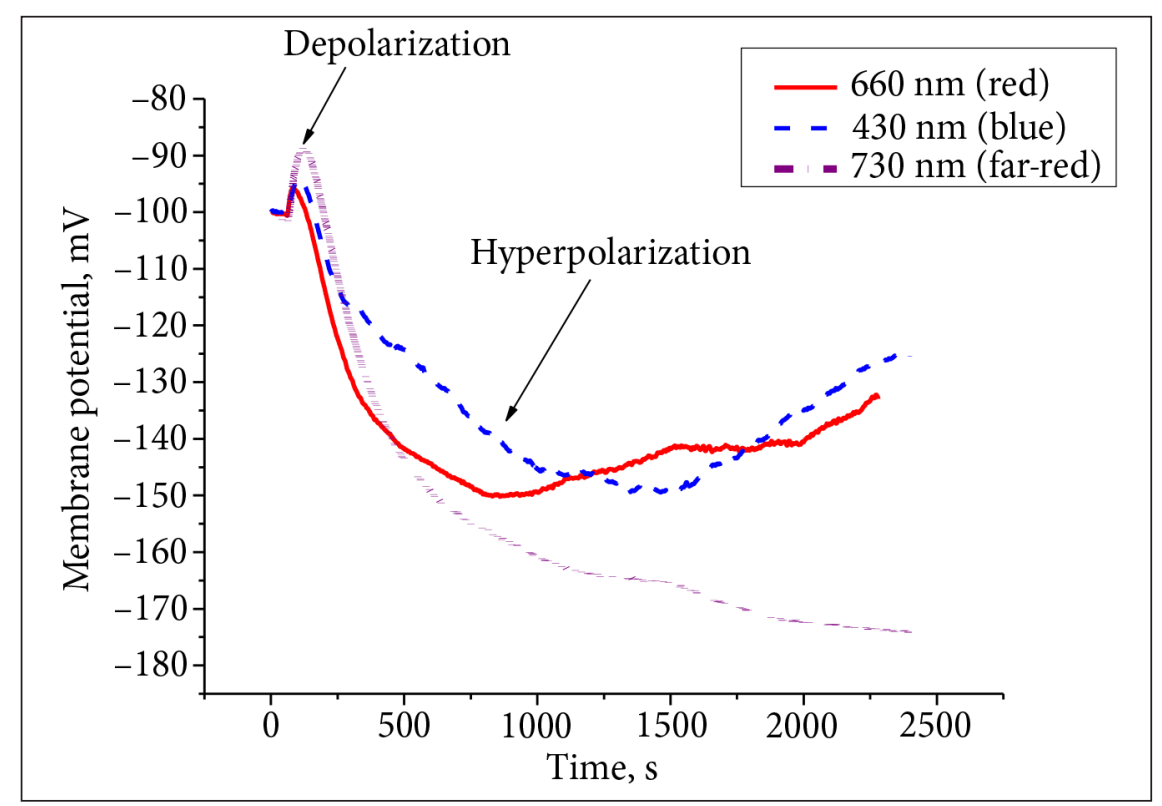

Fig. 3. Typical example of light-induced membrane potential changes after different monochromatic light illumination. Arrows show depolarization and hyperpolarization 


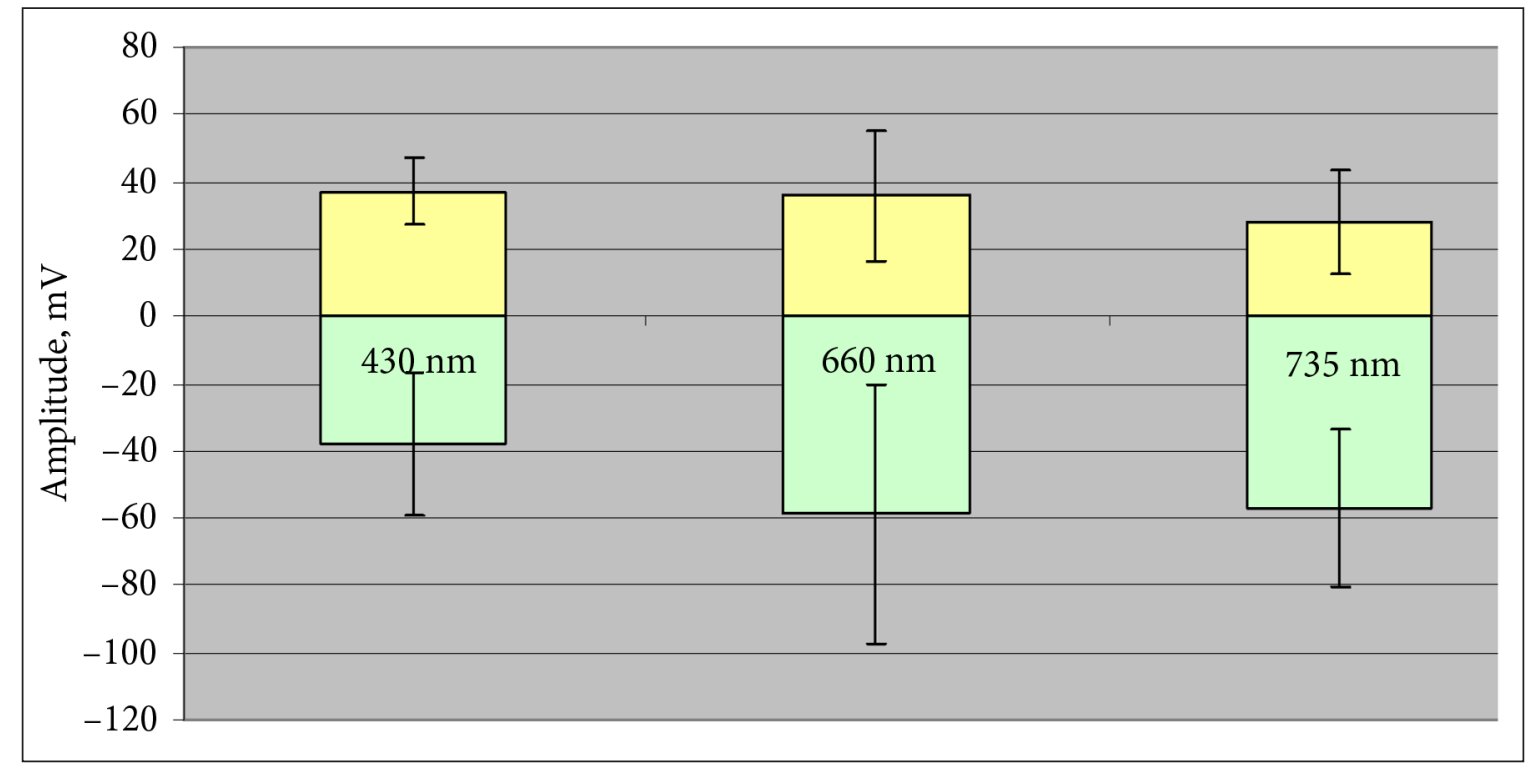

Fig. 4. Averaged long-lasting cell responses to the on / off effect. Hyperpolarization was observed when the test light was switched on, depolarization - when the test light was switched off

on the individual cell properties and statistical analysis reveals the same hyperpolarization process after dark / monochromatic light transition. Accordingly, light / dark transition causes similar responses but in the opposite direction. Statistical analysis did not show significant differences after different illumination (Fig. 4).

In photosynthetic plant cells, the light can rapidly modulate the PM $\mathrm{H}+$-ATPase activity and voltage-dependent ion channels. The evidence indicates that blue light activates the plasma membrane $\mathrm{H}+$-ATPase, producing an outward current that hyperpolarizes the membrane. Blue light directly activates the proton pump (Elzenga et al., 1995), but red light might affect the activity of the pump via calcium and potassium entering through channels in the plasma membrane (Ermolayeva et al., 1996). We observed that onset of every illumination causes a prolonged hyperpolarization which could be explained by activation of the plasma membrane $\mathrm{H}+$-pump. $\mathrm{H}+$ pumping hyperpolarizes the membrane potential, thus creating an electrical gradient (inside negative) required for passive $\mathrm{K}^{+}$uptake through the $\mathrm{K}^{+}$-selective channels (Roelfsema et al., 2001). It was shown that light stimulates potassium uptake, which increases the osmotic potential of the cytoplasm and precedes cell expansion (Živanović et al., 2005). In our experiments we observed some depolarization after long-lasting hyperpolarization (Fig. 3), so we suggested that $\mathrm{K}+$ might act as a charge balancing ion to compensate for $\mathrm{H}+$ extrusion.

If an increase in $\mathrm{Ca}^{2+}$ and depolarization are sufficient to activate anion channels, action potentials are generated (Sukhovet et al., 2011). AP generation depends on cell excitation threshold. In our cases it was averaged $-80 \pm 10 \mathrm{mV}$, and light induced depolarization amplitude was too small to reach the excitation threshold. In contrast to the report of light induced AP in Physcomitrella paterns (Koselski et al., 2008) we recorded action potentials only once in Nitellopsis obtusa cells after red light illumination. It might be related to light intensity, so further investigations are required. However, we could elicit action potentials using electrical stimulation which is typical in excitable plants (Fig. 5).

Amplitude and duration of electrically evoked AP in each illumination were evaluated. We found that at all tested lights irradiation amplitudes did not differ significantly ( $p>0.1$, $\mathrm{n}=6$ ) (Fig. 6, A). However, we found the effect 
of different lighting on AP duration (Fig. 6, B). Duration of AP was evaluated as width of AP half amplitude. We found that AP duration in blue light was $35 \%$ longer than in far-red light $(\mathrm{p}<0.03)$.

It is known that repolarization occurs after the opening of outward rectifying $\mathrm{K}^{+}$channels and activation of the electrogenic proton pump (Beilby, 2007). It was shown that $\mathrm{K}^{+}$ channels and $\mathrm{H}^{+}$-ATPase can be responsible for the differences in AP duration in light- and dark-induced action potentials in Physcomitrella patens (Koselski, 2008). Our results suggest activation of proton pump in far-red light, so significant AP duration difference can be related to more negative MP in this light. Future studies could be performed to investigate the effect of monochromatic light on separate ion transport systems using a voltage clamp method.

Membrane potential changes induced by red light were not reversed or inhibited by far-red light in our investigated cells. Moreover, blue and red light cause the same bioelectrical events in Nitellopsis obtusa cells. It can be concluded that all photoreception systems exert their effects by first altering the permeability of the plasma membrane to ions and later ion channels perform signaltransducing functions in the complex array of mechanisms that determine plant photomorphogenesis.

Received 09 April 2014 Accepted 26 May 2014

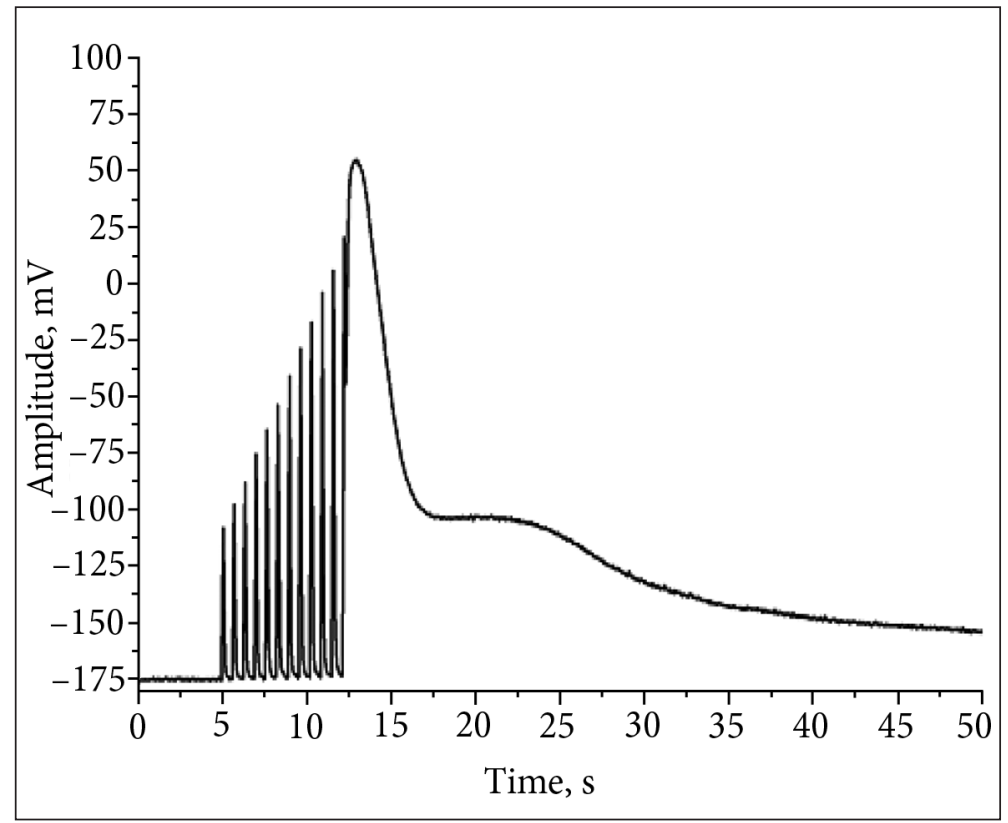

Fig. 5. Typical example of electrically evoked AP of Nitellopsis obtusa cells in blue light

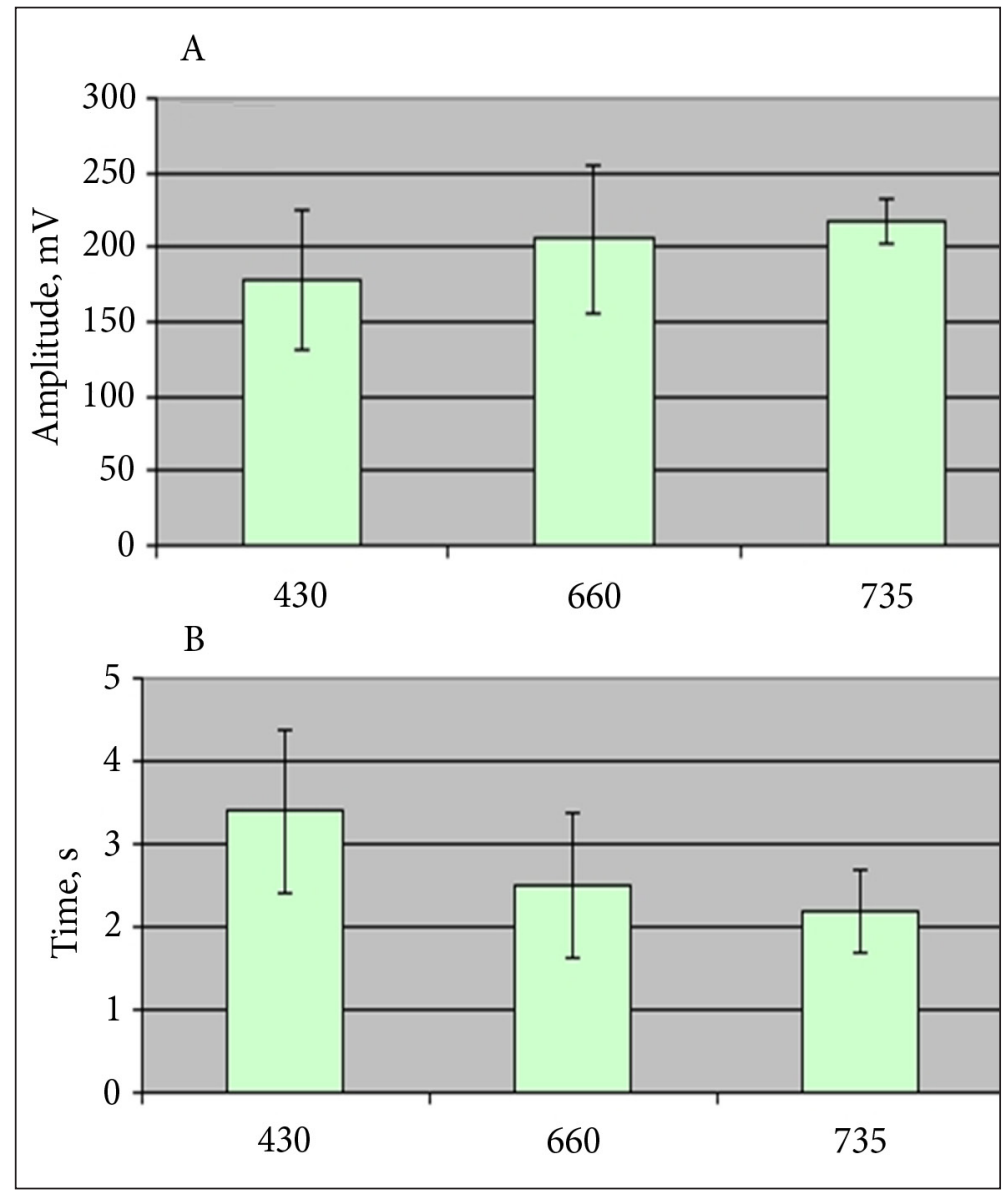

Fig. 6. Amplitude (A) and duration (B) of electrically evoked AP after blue $(430 \mathrm{~nm})$, red $(660 \mathrm{~nm})$ and far-red $(735 \mathrm{~nm})$ light irradiation 


\section{References}

1. Beilby MJ. Action Potential in Charophytes. Int Rev Cytol 2007; 257: 43-82.

2. Blom-Zandstra $\mathrm{M}$, Koot $\mathrm{H}$, van Hattum J, Vogelzang SA. Transient light-induced changes in ion channel and proton pump activities in the plasma membrane of tobacco mesophyll protoplasts. J Exp Bot 1997; 48: 1623-30.

3. Briggs W, Olney M. Photoreceptors in Plant Photomorphogenesis to Date. Five Phytochromes, Two Cryptochromes, One Phototropin, and One Superchrome. Plant Physiol 2001; 125: $185-8$.

4. Chaves I, Pokorny R, Byrdin M, Hoang N, Ritz T, Brettel K, Essen L, Gijsbertus TJ, van der Horst A, Batschauer, Ahmad M. The Cryptochromes: Blue Light Photoreceptors in Plants and Animals. Ann Rev Plant Biol 2011; 62: 335-64.

5. Elzenga JTM, Prins HBA, van Volkenburgh E. Light-induced membrane potential changes of epidermal and mesophyll cells in growing leaves of Pisum sativum. Planta 1995; 197: 127-34.

6. Ermolayeva E, Hohmeyer H, Johannes E, Sanders D. Calcium-dependent membrane depolarization activated by phytochrome in the moss Physcomitrella patens. Planta 1996; 199: 352-8.

7. Ermolayeva E, Sanders D, Johannes E. Ionic mechanism and role of phytochrome mediated membrane depolarization in caulonemal side branch initial formation in the moss Physcomitrella patens. Planta 1997; 201: 10918.

8. Franklin KA, Whitelam GC. Light signals, phytochromes and crosstalk with other environmental cues. J Exp Bot 2004; 55: 271-6.

9. Kagawa T., Wada M. Phytochrome- and bluelight-absorbing pigment-mediated directional movement of chloroplasts in dark-adapted prothallial cells of fern Adiantum as analyzed by microbeam irradiation. Planta 1996; 198: 488-93.
10. Kisnierienė V, Beitas K, Sakalauskas V, Daktariūnas A. Information technologies for biolo education: computerized electrophysiology of plant cells. Informat Educ 2008; 7: 91-104.

11. Koselski M, Trebacz K, Dziubisnka H, Krol E. Light- and dark-induced action potential in Physcomitrella paterns. Plant Signal Behav 2008; 3: 13-8.

12. Kurtyka R, Burdach Z, Karcz W. Effect of cadmium and lead on the membrane potential and photoelectric reaction of Nitellopsis obtusa cells. Gen Physiol Biophys 2011; 30: 52-8.

13. Lunevsky VZ, Zherelova OM, Vostrikov IY, Berestovsky GN. Excitation of Characeae cell membranes as a result of activation of calcium and chloride channels. J Membr Biol 1983; 72: 43-58.

14. Okazaki Y, Tazawa M, Iwasaki H. Lightinduced changes in cytosolic $\mathrm{pH}$ in leaf cells of Egeria densa: measurement with $\mathrm{pH}$-sensitive microelectrodes. Plant Cell Physiol 1994; 35 : 943-50.

15. Roelfsema M, Steinmeyer R, Staal M, Hedrich R. Single guard cell recordings in intact plants: light-induced hyperpolarization of the plasma membrane. Plant J 2001; 26: 1-13.

16. Russell AJ, Cove DJ, Trewavas AJ, Wang TL. Blue light but not red light induces a calcium transient in the moss Physcomitrella patens (Hedw.). Planta 1998; 206: 278-83.

17. Shabala S, Newman I. Light-Induced Changes in Hydrogen, Calcium, Potassium, and Chloride Ion Fluxes and Concentrations from the Mesophyll and Epidermal Tissues of Bean Leaves. Understanding the Ionic Basis of Light-Induced Bioelectrogenesis. Plant Physiol 1999; 119: 1115-24.

18. Shimmen T, Mimura T, Kikuyama $M$, Tazawa M. Characean cells as a tool for studying electrophysiological characteristics of plant cells. Cell Struct Funct 1994; 19: 26378.

19. Spalding EP. Ion channels and the transduction of light signals. Plant Cell Environ 2000; 23: 665-74. 
20. Stahlberg R, Stephens RN, Cleland ER, van Volkenburgh E. Shade-Induced Action Potentials in Helianthus annuus L. Originate Primarily from the Epicotyl. Plant Signal Behav 2006; 1: 15-22.

21. Sukhov V, Nerush V, Orlova L, Vodeneev V. Simulation of action potential propagation in plants. J Theor Biol 2011; 291: 47-55.

22. Szarek I, Trebacz K. The Role of Light-Induced Membrane Potential Changes in Guttation in Gametophytes of Asplenmium trichomanes. Plant Cell Physiol 1999; 40: 1280-6.

23. Thiel G, Homann U, Plieth C. Ion channel activity during the action potential in Chara: a new insight with new techniques. J Exp Bot 1997; 48: 609-22.

24. Ulijasz TA, Vierstra DR. Phytochrome structure and photochemistry: recent advances toward a complete molecular picture. Curr Opin Plant Biol 2011; 14: 1-9.

25. Zimmermann S, Ehrhardt T, Plesch G, Mueller-Roeber B. Ion channels in plant signaling. Cell Mol Life Sci 1999; 55: 183-203.

26. Živanović BD, Pang J, Shabala S. Light-induced transient ion flux responses from maize leaves and their association with leaf growth and photosynthesis. Plant Cell Environ 2005; 28: 340-52.
Vilma Kisnierienė, Jonas Burneika, Indrè Lapeikaitė, Olga Sevriukova, Algis Daktariūnas

\section{MÉLYNOS, RAUDONOS IR TOLIMOS \\ RAUDONOS ŠVIESOS POVEIKIO \\ NITELLOPSIS OBTUSA LĄSTELIŲ \\ MEMBRANINIAM POTENCIALUI TYRIMAS}

\section{Santrauka}

Šviesa kontroliuoja įvairius augalų fiziologinius procesus. Membraninio potencialo pokyčiai atspindi ląstelių jonų pernašos sistemų veiklą, todèl šiame darbe buvo tiriamas monochromatinès šviesos poveikis Nitellopsis obtusa ląstelių elektrofiziologiniams parametrams. Membraninio potencialo pokyčiai buvo registruojami naudojant ekstraląstelinị " $\mathrm{K}^{+}$anestezija" metodą. Mèlynos, raudonos ir tolimos raudonos šviesos šaltiniais pasirinktos trys $430 \mathrm{~nm}, 660 \mathrm{~nm}$ ir $735 \mathrm{~nm}$ bangos ilgių šviestukų matricos. Buvo vertinama fotoelektrinè reakcija ir ląstelių sužadinimas. Nustatyta, kad visų tirtų bangos ilgių šviesos ijungimas ir išjungimas daro toki patị tiesiogini poveiki membranos potencialui, veikimo potencialo generavimui bei jo parametrams.

Raktažodžiai: augalų fotoreceptoriai, membraninis potencialas, augalų elektriniai signalai, augalų fotoelektrinè reakcija 